\title{
PENINGKATAN KEMAMPUAN MENULIS TEKS PIDATO MENGgUNAKAN MODEL PEMBELAJARAN KUMON SISWA KELAS X MA AL-MUHAJIRIN TUGUMULYO
}

\author{
DIAN RAMADAN LAZUARDI \\ Program Studi Pendidikan Bahasa dan Sastra Indonesia, \\ Jurusan Pendidikan Bahasa dan Seni STKIP-PGRI Lubuklinggau \\ Jalan Mayor Toha Kelurahan Air Kuti Lubuklinggau \\ dianramadan78@gmail.com
}

Pertama Diterima: I I Juni 2019

Bukti Akhir Diterima: 24 September 2019

\begin{abstract}
Abstrak
Penelitian ini bertujuan untuk meningkatkan kemampuan menulis teks pidato siswa kelas $\mathrm{X}$ MA Al-Muhajirin Tugumulyo menggunakan model pembelajaran kumon yang berjumlah 32 orang siswa. Penelitian ini menggunakan pendekatan penelitian tindakan kelas (classroom action research). Teknik pengumpulan data dalam penelitian ini menggunakan teknik tes. Hasil data tes dianalisis dengan melihat nilai rata-rata peningkatan pada pratindakan, siklus I, dan siklus II. Teknik analisis data dilakukan dengan cara menjumlahkan skor dari indikator penilaian yang diperoleh siswa. Pada kegiatan pratindakan nilai rata-rata siswa sebesar $71,71 \%$ dengan ketuntasan sebesar $34,38 \%$ dengan jumlah siswa tuntas sebanyak 11 orang dan yang tidak tuntas sebanyak 21 orang. Tindakan siklus I, nilai rata-rata siswa 75,53 dan ketuntasan hanya mencapai $71,88 \%$ dengan jumlah siswa tuntas sebanyak 23 orang dan tidak tuntas sebanyak 9 orang. Sedangkan pada siklus II nilai rata-rata mencapai 80,93 dengan jumlah siswa tuntas sebanyak 30 orang dan tidak tuntas 2 orang, berarti dari siklus I sampai siklus II meningkat sebesar $21,87 \%$.. Simpulan, melalui model pembelajaran kumon kemampuan menulis teks pidato meningkat.
\end{abstract}

Kata Kunci: Teks pidato, pembelajaran, kumon.

\begin{abstract}
This study aims to improve the ability to write speech texts in class X MA AlMuhajirin Tugumulyo using a kumon learning model of 32 students. This research uses a classroom action research approach. Data collection techniques in this study used test techniques. The results of the test data were analyzed by looking at the average value of the increase in pre-action, cycle I, and cycle II. Data analysis technique is done by adding up scores from assessment indicators obtained by students. In the pre-action activities the average value of students was $71.71 \%$ with completeness of $34.38 \%$ with the number of students as many as 11 people and as many as 21 people who did not complete. The first cycle of action, the average value of students 75.53 and completeness only reached $71.88 \%$ with the total number of students as many as 23 people and not as many as 9 people. While in cycle II the average value reached 80.93 with 30 students completing as many students and not completing 2 people, meaning that from cycle I to cycle II increased by $21.87 \%$. increased.
\end{abstract}

Keywords: Speech text, learning, kumon. 


\section{PENDAHULUAN}

Menulis teks pidato adalah salah satu kompetensi yang harus dikuasai oleh siswa kelas X MA Al-Muhajirin yang diwujudkan dengan standar kompetensi mengungkapkan informasi melalui penulisan paragraf dan teks pidato. Standar kompetensi ini harus dikuasai oleh siswa untuk melatih dan meningkatkan kemampuan menulis teks pidato. Pada hakikatnya, menulis teks pidato adalah kegiatan komunikasi yang menggunakan media tulis berupa lambang-lambang huruf atau angka untuk memberitahu kepada pembaca/khalayak mengenai ide dan gagasan penulis sesuai situasi dan konteks.

Menurut Dalman (2015:4) menulis adalah proses penyampaian pikiran, angan-angan, perasaaan dalam bentuk lambang/ tanda/ tulisan yang bermakna. Dalam hal ini, menulis itu membutuhkan skema yang luas sehingga penulis mampu menuangkan ide, gagasan, pendapatnya dengan mudah dan lancar. Skema itu sendiri adalah pengetahuan dan pengalaman yang dimiliki penulis. Jadi, semakin luas skema seseorang semakin mudahlah penulis menuangkan ide dan gagasannya, dalam hal ini juga termasuk menulis teks pidato. Hal ini juga senada dengan pendapat Suparno dan Yunus (2015:15) menulis merupakan suatu kegiatan penyampaian pesan (komunikasi) dengan menggunakan bahasa tulis sebagai alat atau medianya. Kemampuan menulis inilah khususnya menulis teks pidato yang harus dikuasai oleh siswa.

Permasalahan yang sering dihadapi oleh guru mata pelajaran Bahasa Indonesia, dalam mengajar menulis teks pidato yaitu rendahnya kemampuan siswa dalam menulis teks pidato yang disebabkan oleh berbagai faktor, yaitu rendahnya minat dan motivasi siswa dalam hal menulis khususnya menulis teks pidato. Siswa merasa kesulitan menuangkan ide dan gagasan untuk menulis teks pidato dikarenakan juga kelengkapan sarana pembelajaran dan penerapan dalam proses mengajar yang kurang kreatif, guru sibuk menjelaskan materi tanpa memperhatikan kondisi siswa di dalam kelas sehingga membuat siswa bosan dan jenuh untuk mengikuti kegiatan pembelajaran.

Untuk memperoleh hasil belajar yang maksimal dibutuhkan sebuah model pembelajaran. Salah satu model pembelajaran yang dapat meningkatkan kemampuan menulis teks pidato adalah model pembelajaran kumon. Model pembelajaran kumon adalah model pembelajaran dengan mengaitkan antara konsep, keterampilan, kerja individual dan menjaga suasana nyaman dan menyenangkan. Sistem pembelajaran dengan model kumon menurut Kurniasih (2013:120) pembelajarannya disesuaikan dengan keterampilan dan potensi masing-masing siswa. Model pembelajaran kumon tidak hanya mengajarkan cara belajar tetapi juga dapat meningkatkan keterampilan peserta didik untuk lebih fokus dalam mengerjakan sesuatu dan juga dapat meningkatkan rasa percaya diri. Digunakannya model pembelajaran kumon karena memeiiki beberapa kelebihan yaitu, bahan pelajaran tersusun atas langkah-langkah kecil sehingga anak bisa memperoleh keterampilan dasar yang kuat. Kelebihan selanjutnya yaitu siswa mengerjakan tugas secara mandiri dari tingkat yang mudah sampai tingkat yang lebih sulit, bila mengalami kesulitan bisa melihat buku penyelesaian sehingga pembelajaran akan lebih bermakna (Shoimin, 2016:94).

Hasil penelitian yang relevan yang berkaitan dengan peningkatan kemampuan menulis teks pidato yaitu penelitian yang dilakukan oleh Septaviani (2017) menggunakan model pembelajaran Cooperative Group Investigation, model ini sama-sama melihat kemampuan menulis teks pidato dengan menggunakan model yang berbeda. Hasil penelitian menunjukkan bahwa adanya 
peningkatan kemampuan menulis teks pidato menggunakan model pembelajaran Cooperative Group Investigation. Berdasarkan analisis data, sebelum adanya tindakan nilai rata-rata siswa $68,2 \%$. Setelah dilaksanakan siklus 1 adanya peningkatan menjadi 70,25\%, dan meningkat lagi pada siklus 2 menjadi 79,48\%. Penelitian ini dilaksanakan untuk membuktikan adakah peningkatan kemampuan menulis teks pidato menggunakan model pembelajaran kumon? dengan harapan menjadi salah satu alternatif bagi guru Bahasa Indonesia dalam meningkatkan kemampuan menulis khususnya kemampuan menulis teks pidato.

\section{METODE PENELITIAN}

Dalam penelitian ini metode yang digunakan adalah penelitian tindakan kelas. Penelitian ini berusaha mengkaji, merefleksikan secara kritis, dan kolaboratif suatu rencana pembelajaran terhadap kinerja guru serta interaksi antara guru dan siswa (Arikunto, 2007). Penelitian ini dilaksanakan di MA Al-Muhajirin Tugumulyo. Subjek penelitian ini adalah siswa kelas X MA AlMuhajirin Tugumulyo dan objeknya adalah kemampuan menulis teks pidato siswa kelas X MA AlMuhajirin dengan menggunakan model pembelajaran kumon. Penelitian tindakan ini direncanakan dalam dua siklus. Dalam pelaksanaannya, masing-masing siklus akan mengikuti tahap-tahap yang ada dalam penelitian tindakan kelas yaitu perencanaan, implementasi tindakan, observasi dan refleksi. Setiap sikus diadakan penyempurnaan tindakan sesuai dengan hasil refleksi pada siklus sebelumnya, sehingga diperoleh hasil yang optimal. Data dalam penelitian ini diambil dengan teknik tes. Teknik analisis data digunakan untuk membuktikan kemampuan siswa dalam menulis teks pidato. Untuk mengetahui hasil belajar mahasiswa secara individu dilakukan dengan cara menjumlahkan skor dari indikator penilaian yang diperoleh siswa.

\section{HASIL PENELITIAN DAN PEMBAHASAN}

\section{Hasil Penelitian}

Penelitian ini dilaksanakan di kelas X MA-Almuhajirin Tugumulyo dengan jumlah siswa sebanyak 32 orang terdiri dari 12 siswa laki-laki dan 20 siswa perempuan. Berdasarkan hasil penelitian pratindakan yang memperoleh nilai $\geq 75$ atau tuntas berjumlah 11 orang dengan persentase sebesar $34,38 \%$. Selanjutnya mahasiswa yang memperoleh nilai $\leq 75$ atau belum tuntas berjumlah 21 orang dengan persentase sebesar 65,62\%. Nilai rata-rata pada pratindakan adalah 71,71. Rincian hasil kegiatan belajar mengajar pada pratindakan dapat dilihat pada tabel berikut ini:

Tabel 1. Pratindakan

\begin{tabular}{|c|c|c|c|c|c|}
\hline \multirow[t]{2}{*}{$\begin{array}{c}\text { Pelaksanaan } \\
\text { Tindakan }\end{array}$} & \multirow[t]{2}{*}{ Jumlah siswa } & \multicolumn{2}{|c|}{ Tuntas } & \multicolumn{2}{|c|}{ Tidak Tuntas } \\
\hline & & Jumlah siswa & $\%$ & Jumlah siswa & $\%$ \\
\hline Pratindakan & 32 & 11 & 34,38 & 21 & 65,62 \\
\hline
\end{tabular}

\section{Siklus I}

Pada tindakan siklus I siswa sudah diperkenalkan dengan model kumon, proses pembelajaran sudah terlihat ada peningkatan, ketika diajak berkomunikasi siswa mulai terlihat sedikit aktif terlibat dalam proses pembelajaran dan proses pembelajaran terlihat menjadi menyenangkan. Pada 
tindakan siklus I, nilai rata-rata siswa hanya mencapai 75,53. Berdasarkan hasil penelitian siklus I yang memperoleh nilai $\geq 75$ atau tuntas berjumlah 23 orang dengan persentase sebesar $71,88 \%$. Selanjutnya mahasiswa yang memperoleh nilai $\leq 75$ atau belum tuntas berjumlah 9 orang dengan persentase sebesar 28,12\%. Rincian hasil kegiatan belajar mengajar pada siklus I dapat dilihat pada tabel berikut ini:

Tabel 2. Siklus I

\begin{tabular}{ccccc}
\hline $\begin{array}{c}\text { Pelaksanaan } \\
\text { Tindakan }\end{array}$ & Jumlah siswa & Tuntas & & Tidak Tuntas \\
\cline { 3 - 5 } & & & & \\
\hline & 32 & Jumlah siswa & Jumlah siswa & 9 \\
\hline Siklus I & 23 & 71,88 & 28,11 \\
\hline
\end{tabular}

\section{Siklus II}

Pada tindakan siklus II menunjukkan adanya peningkatan kemampuan siswa dalam menulis teks pidato, siswa mampu membuat teks pidato secara mandiri, siswa terlihat semakin bersemangat, aktif, antusias, dan kreatif dalam mengeluarkan ide-ide sehingga suasana pembelajaran menjadi sangat menyenangkan. Siswa mulai merasa bahwa menulis teks pidato tidaklah sulit. Melihat proses pembelajaran tersebut, dapat disimpulkan bahwa penerapan model pembelajaran kumon merupakan salah satu pilihan yang tepat dalam upaya meningkatkan kemampuan menulis teks pidato. Hal ini sejalan dengan pendapat Anwar (2012:4) model pembelajaran kumon menekankan pada kemandirian siswa dalam memecahkan masalah, siswa dituntut mahir untuk menyelesaikan tugastugas dengan matang sesuai dengan kemampuannya. Melalui pencapaian target dengan kemampuannya sendiri, anak-anak akan merasa kegembiraan dan kepuasan.Dari hasil penilaian siklus II nilai rata-rata siswa mencapai 80,93, yang memperoleh nilai $\geq 75$ atau tuntas berjumlah 30 orang dengan persentase sebesar 93,75\%. Selanjutnya mahasiswa yang memperoleh nilai $\leq 75$ atau belum tuntas berjumlah 2 orang dengan persentase sebesar 6,25\%. Rincian hasil kegiatan belajar mengajar pada siklus II dapat dilihat pada tabel berikut ini:

Tabel 3. Siklus II

\begin{tabular}{cccccc}
\hline \multirow{2}{*}{$\begin{array}{c}\text { Pelaksanaan } \\
\text { Tindakan }\end{array}$} & Jumlah siswa & \multicolumn{3}{c}{ Tuntas } & \multicolumn{2}{c}{ Tidak Tuntas } \\
\cline { 3 - 6 } & & Jumlah siswa & $\%$ & Jumlah siswa & $\%$ \\
\hline Siklus II & 32 & 30 & 93,75 & 2 & 6,25 \\
\hline
\end{tabular}

Terjadinya peningkatan kemampuan siswa dalam menulis teks pidato dikarenakan pada siklus II dilakukan perbaikan-perbaikan berdasarkan kekurangan yang terjadi pada siklus I dan pratindakan. Berikut ini disajikan peningkatan kemampuan mahasiswa dari pratiindakan, siklus I, dan siklus II : 
Tabel 4. Peningkatan Kemampuan Siswa Menulis Teks Pidato Per-siklus

\begin{tabular}{cccccc}
\hline \multirow{2}{*}{$\begin{array}{c}\text { Pelaksanaan } \\
\text { Tindakan }\end{array}$} & Jumlah siswa & \multicolumn{3}{c}{ Tuntas } & \multicolumn{2}{c}{ Tidak Tuntas } \\
\cline { 3 - 6 } & & & & & \\
& & Jumlah siswa & 34,38 & Jumlah siswa & $\%$ \\
\hline Pratindakan & 32 & 11 & 71,88 & 21 & 65,62 \\
\hline Siklus I & 32 & 23 & 93,75 & 2 & 6,25 \\
\hline Siklus II & 32 & 30 & & & 28,11 \\
\hline
\end{tabular}

\section{Pembahasan}

\section{Tiap Siklus dan Antar Siklus}

Data yang diperoleh saat pratindakan dari 32 orang siswa, yang tuntas 11 orang dengan persentase $34,38 \%$, sedangkan siswa yang tidak tuntas 21 orang dengan persentase $65,62 \%$, nilai rata-rata yang diperoleh pada pratindakan adalah 71,71. Selanjutnya pada siklus I secara klasikal kegiatan pembelajaran belum mencapai syarat ketuntasan 85\%, secara klasikal kegiatan pembelajaran belum tuntas. Siswa yang memperoleh nilai $\geq 75$ hanya mencapai $71,88 \%$. Berdasarkan hal inilah perlu dilanjutkan ke siklus II. Pada siklus II siswa yang tuntas sebanyak 30 orang dengan persentase $93,75 \%$, siswa yang belum tuntas sebanyak 2 orang dengan persentase $6,25 \%$. Dari hasil penilaian ini menunjukkan bahwa adanya peningkatan dalam menulis teks pidato.

\section{Pembahasan Antarsiklus}

Pada kegiatan pratindakan nilai rata-rata siswa sebesar $71,71 \%$ dengan ketuntasan sebesar $34,38 \%$ dengan jumlah siswa tuntas sebanyak 11 orang dan yang tidak tuntas sebanyak 21 orang. Tindakan siklus I, nilai rata-rata siswa 75,53dan ketuntasan hanya mencapai 71,88\% dengan jumlah siswa tuntas sebanyak 23 orang dan tidak tuntas sebanyak 9 orang. Sedangkan pada siklus II nilai rata-rata mencapai 80,93 dengan jumlah siswa tuntas sebanyak 30 orang dan tidak tuntas 2 orang, berarti dari siklus I sampai siklus II meningkat sebesar 21,87\%. Peningkatan tersebut dapat dilihat pada rumus berikut ini:

$$
\mathrm{P}=\frac{\mathrm{R} 2-\mathrm{R} 1 \times 100 \%}{\mathrm{R} 1}
$$

Keterangan:

$\mathrm{P}=$ Persentase peningkatan kemampuan

$\mathrm{R} 1=$ Nilai rata-rata sebelum tindakan

R2 = Nilai rata-rata sesudah tindakan siklus I dan siklus II

Berdasarkan rumus di atas, dari hasil hasil penelitian diketahui R1 sebesar 71,72 dan nilai R2 sebesar 78,23. Nilai R2 ini diperoleh dari menjumlahkan nilai rata-rata siklus I 75,53 dan siklus II 80,93 kemudian dibagi dua diperoleh hasil 78,23. Langkah selanjutnya yaitu memasukkan nilai R1 dan nilai R2 ke dalam rumus yaitu nilai R2 sebesar 78,23dikurangi nilai R1 sebesar 71,72 kemudian 
dibagi nilai R1 sebesar 71,72 dan dikalikan 100, sehingga diperoleh hasil 9,07\%. Jika dibandingkan antara pratindakan dan akhir siklus II terjadi peningkatan nilai rata-rata sebesar 59,37\%, sedangkan peningkatan nilai rata-rata kemampuan mahasiswa dari pratindakan ke tindakan siklus I dan siklus II sebesar $37,50 \%$ diketahui tuntas 30 orang siswa dari 32 orang siswa, persentase ketuntasan mencapai 93,75\%.

Berdasarkan hipotesis tindakan dapat dinyatakan bahwa penggunaan model kumon dapat meningkatkan kemampuan menulis teks pidato siswa kelas X MA Al-Muhajirin Tugumulyo. Hal ini dapat dilihat dari nilai ketuntasan pada akhir penelitian sebesar 93,75\%.Guru telah membimbing siswa dengan efektif dan tepat, guru mengaitkan antar konsep, keterampilan dan mengerjakan tugas secara perseorangan sesuai dengan kemampuan masing-masing, sehingga siswa merasa suasana pembelajaran menjadi lebih nyaman dan menyenangkan dengan memahami potensi dan kemampuan siswa inilah kemampuan menulis teks pidato meningkat. Hal ini sejalan dengan pendapat Anwar (2012:5) yang menyatakan bahwa model pembelajaran kumon yang diberikan perseorangan kepada siswa pada tingkatan dan porsi yang tepat akan mengembangkan kemampuan atau potensi siswa dalam pembelajaran. Model ini juga dapat meningkatkan kosentrasi, ketangkasan kerja, kemampuan berpikir, dan rasa percaya diri.

\section{PENUTUP}

Berdasarkan analisis data dan pembahasan hasil penelitian secara umum dapat disimpulkan bahwa dengan menerapkan model pembelajaran kumon kemampuan menulis teks pidato pada siswa kelas X MA Al-Muhajirin Tuhumulyo dapat meningkat, sedangkan simpulan khusus dari penelitian ini adalah sebagai berikut: Kemampuan menulis teks pidato pada siswa kelas X MA Al-Muhajirin Tuhumulyo dapat ditingkatkan dengan model pembelajaran kumon karena dengan menerapkan model pembelajaran kumon suasana pembelajaran menjadi lebih nyaman dan menyenangkan. Hal ini dapat dilihat dari rata-rata nilai tes pratindakan sebesar 71,71 rata-rata nilai tes siklus I 75,53, dan rata-rata nilai tes siklus II sebesar 80,93.

Data yang diperoleh saat pratindakan dari 32 orang siswa, yang tuntas 11 orang dengan persentase $34,38 \%$, sedangkan mahasiswa yang tidak tuntas 21 orang dengan persentase $65,62 \%$, nilai rata-rata yang diperoleh pada pratindakan adalah 71,71. Selanjutnya, pada siklus I secara klasikal kegiatan pembelajaran belum mencapai syarat ketuntasan $85 \%$, secara klasikal kegiatan pembelajaran belum tuntas. Siswa yang memperoleh nilai $\geq 75$ hanya mencapai $71,88 \%$. Berdasarkan hal inilah perlu dilanjutkan ke siklus II. Pada siklus II siswa yang tuntas sebanyak 30 orang dengan persentase $93,75 \%$, siswa yang belum tuntas sebanyak 2 orang dengan persentase $6,25 \%$. Dari hasil penilaian ini menunjukkan bahwa adanya peningkatan dalam menulis teks pidato. 


\section{DAFTAR PUSTAKA}

Anwar. (2012). Perencanaan Sistem Pembelajaran. Bandung: Alfabeta.

Arikunto, Suharsimi. (2007). Penelitian Tindakan Kelas. Jakarta: Bumi Aksara.

Dalman. (2015). Keterampilan Menulis. Jakarta: Raja Grafindo Persada.

Kurniasih, Imas. (2013). Ragam Pengembangan Model Pembelajaran. Jakarta: Kata Pena.

Septaviani, Ertin Dwi. (2016). Peningkatan Keterampilan Menulis Teks Pidato dengan Model Pembelajaran Cooperative Group Investigation Pada Siswa Kelas X A SMA Negeri 1 Samalantan. Jurnal Pendidikan Bahasa dan Sastra Indonesia, 1(1), 1-5. journal.stkipsingkawang.ac.id/index.php/JP-BSI/article/view/68/46

Shoimin, Aris. (2016). 68 Model Pembelajaran Inovatif dalam Kurikulum 2013. Yogyakarta: ArRuzz Media.

Suparno, Yunus Muhammad. (2015). Keterampilan Dasar Menulis. Jakarta: Universitas Terbuka. 